KS. DOMINIK ZAMIATAŁA CMF* - WARSZAWA

\title{
WLADZE KOMUNISTYCZNE WOBEC ZAKONÓW MĘSKICH NA ŚRODKOWYM NADODRZU W LATACH 1970-1980
}

Zmiany na szczytach komunistycznej władzy w Polsce w wyniku wypadków grudniowych na Wybrzeżu w 1970 r. wpłynęły na zmianę postępowania komunistów wobec Kościoła katolickiego i zakonów. Nowa ekipa z Edwardem Gierkiem na czele, świadoma wpływów Kościoła katolickiego w społeczeństwie postępowała ,Z większą niż poprzednio oględnością” w realizacji założeń państwa świeckiego. Oficjalnie zliberalizowała politykę wobec Kościoła, ale nieoficjalnie nadal dążyła do neutralizacji jego wpływów w społeczeństwie polskim ${ }^{1}$.

Komuniści dużo mówili w latach siedemdziesiątych o wspólistnieniu państwa i Kościoła w PRL, jednocześnie w bardziej zakamuflowany sposób, kontynuowali z nim walkę na płaszczyźnie ideologicznej². Kościół był oskarżany o próby przeciwstawiania wiernych władzy państwowej i inspirowania do ,szkodliwych działań" wobec państwa ${ }^{3}$, dlatego w planach operacyjnych organów bezpieczeństwa wciąż podkreślano pracę nad ograniczaniem i osłabianiem działalność Kościoła, zwłaszcza zakonów, które nadal dla komunistycznej władzy były organizacjami zwartymi i jednolitymi w swoich działaniach o charakterze politycznym ${ }^{4}$. Władza ludowa zdawała sobie sprawę, że pozycja zakonów w społeczeństwie polskim, w kolejnej dekadzie PRL, nadal była dosyć silna. Wiedziała, że zakonnicy rozumieli swoją rolę wśród ludności, w Kościele i starali się dobrze ją spełniać. Była

* ks. Dominik Zamiatała - dr hab. historii, profesor w Instytucie Politologii UKSW, e-mail: dominikzm@interia.pl

${ }^{1}$ Z. Zieliński, Kościół w kręgu rzeczywistości politycznej, Lublin 2003, s. 174

${ }^{2}$ A. Łopatka, Zasady polityki wyznaniowej, Warszawa 1987, s. 5; K. Kąkol, Stosunki między państwem i Kościolem w PRL. Materiały szkoleniowe dla aktywu związowego, Warszawa 1983, s. 7.

${ }^{3}$ Instytut Pamięci Narodowej (dalej: IPN), sygn. 0639/99, IPN, sygn. 0639/99, Program działania Resortu Spraw Wewnętrznych w latach 1972-1975, k. 3-4.

${ }^{4}$ Archiwum Akt Nowych (dalej: AAN), UdsW, sygn. 133/15, E. Sztekker, Informacja o działalności zakonów i zgromadzeń zakonnych z 9 III 1976 roku, k. 163-164. 
przekonana, że w działalności duszpasterskiej mieli duży wpływ na wiernych i w swoich parafiach $\mathrm{z}$ łatwością gromadzili dzieci i młodzież. W ich opinii uchodzili za doskonałych specjalistów od inteligencji, młodzieży, misji i rekolekcji ${ }^{5}$.

W związku z powyższym, dla komunistycznej władzy, nadal strategicznym celem w oddziaływaniu na duchowieństwo było „przyjęcie przez zakony lojalnej postawy wobec PRL-u" oraz ich polityczna neutralizacja, a w dalszym etapie podporządkowanie zakonów władzy państwowej. Celem doraźnym natomiast stało się eliminowanie z działalności zakonników „szkodliwych akcentów politycznych i naruszania porządku prawnego", umacnianie postaw lojalnych zakonników, tam gdzie już występowały, „przekierunkowanie” ich oddziaływań w sposób korzystny dla władz państwowych. $Z$ punku widzenia ideologicznego władze starały się powstrzymywać rozszerzanie i umacnianie przez poszczególne zakony wpływów religijnych w społeczeństwie, szczególnie wśród młodzieży, zapobiegać wygłaszaniu przez kapłanów zakonnych kazań o treści wrogiej, czy nieprzychylnej dla komunistycznej władzy, eliminować uleganie inspiracjom biskupów do samowoli budowlanej, tworzenie nowych placówek zakonnych bez zgody władz państwowych i skłonienie ich do realizacji wyłącznie polityki państwa ${ }^{6}$.

Bezpośrednio realizacją polityki wobec zakonów zajmował się aparat wyznaniowy oraz aparat represji na czele z IV Wydziałem MSW ${ }^{7}$. Na terenie Środkowego Nadodrza odpowiedzialnym organem za działania wobec zakonów oraz kształtowanie obywatelskiej i lojalnej postawy zakonników wobec państwa, był wydział do spraw wyznań (od 1975 roku, po nowym podziale administracyjnym - Wydział do Spraw Wyznań w Gorzowie Wielkopolskim).

Wydział wyznań w prowadzeniu lokalnej polityki wobec zakonów musiał się też w zasadniczych sprawach podporządkować decyzjom centralnym Urzędu do Spraw Wyznań w Warszawie (UdsW), który prowadził całościową politykę pracy z zakonami, ponieważ - jak czytamy w jednym z dokumentów tego urzę$\mathrm{du}$ - zakony „,w przeciwieństwie do kurii diecezjalnych położonych w zasadzie na terenie jednego lub najwyżej dwóch województw, mają rozsiane placówki w wielu województwach, a często na terenie całego kraju, co wymaga centralnego sterowania polityką w stosunku do nich [zakonów - D.Z.], przy uwzględnieniu opinii i oceny ich postawy w ogólnym przekroju terytorialnym i wspomnianych już układów wewnętrzno-organizacyjnych"». W koordynacji działań wojewódzkiego wydziału wyznań z UdsW obowiązywała generalna zasada nadrzędności polityki wobec zakonu jako całości, nad względami lokalnymi ${ }^{9}$. Terenowe władze wyznaniowe, w oparciu o odgórne decyzje, były zobligowane do opracowania na

${ }^{5}$ AAN, UdsW, sygn. 133/12, Postulaty merytoryczne i organizacyjne, k. 83; AAN, UdsW, sygn. 133/17, Informacja o stanie posiadania i działalności zgromadzeń zakonnych (męskich i żeńskich) na terenie województwa gorzowskiego wg. stanu na dzień 30 czerwca 1980 r., k. 119.

${ }^{6} \mathrm{AAN}, \mathrm{UdsW}$, sygn. 133/12, Postulaty merytoryczne i organizacyjne, k. 83.

${ }^{7}$ D. Zamiatała, Zakony męskie $w$ polityce władz komunistycznych $w$ Polsce $w$ latach 1945 1989, t. I, Problematyka organizacyjno-personalna, Kielce 2009, s. 47, 56.

${ }^{8}$ AAN, UdsW, sygn. 142/1, Informacja o aktualnej sytuacji i zasadach w pracy z zakonami, k. 242.

${ }^{9}$ Tamże, k. 244. 
swoim terenie metod i środków wobec zakonu, jakich należałoby użyć do osiągnięcia określonych celów dla państwa ludowego ${ }^{10}$. Wydziały ds. Wyznań mogły też zgłaszać swoje propozycje dotyczące postępowania wobec zakonów w całym kraju. Wydział z woj. gorzowskiego, np. postulował pogłębianie izolacji między duchowieństwem diecezjalnym a zakonnym, umacnianie pozycji księży zakonnych w stosunku do diecezjalnych, systematyczne wizytowanie domów zakonnych oraz zwiększenie zakresu kontaktów z zakonami ${ }^{11}$.

Wydziały ds. Wyznań z terenu Środkowego Nadodrza, podobnie jak Wydziały z innych części kraju, na polecenie Urzędu ds. Wyznań, zwracały szczególną uwagę na to, by polityka wobec zakonów była elastyczna, dzięki czemu oddziaływanie na poszczególne domy zakonne - jak sądzono - zaowocuje większą lojalnością zakonników wobec władz państwowych i unikaniem przez duchownych wystąpień krytykujących obecny system ${ }^{12}$. W omawianej dekadzie wydziały wyznań w pracy z zakonami zgodnie z odgórnymi decyzjami nadal starały się neutralizować zakonników pod względem politycznym od wpływów biskupów. W dalszym ciągu realizowały zadanie zmuszenia zakonów do respektowania zasad społeczno-ustrojowych i obowiązujących przepisów państwowych. Na bieżąco opracowywały, a następnie dostarczały UdsW w Warszawie, informacje dotyczące ogólnej oceny aktualnej postawy i działalności zakonu na terenie swojego województwa, jego zasięgu społecznego i skuteczności oddziaływania na konkretne środowiska katolickie, potrzeb i możliwości zaangażowania zakonu do rozwiązywania nabrzmiałych problemów społecznych lub wewnątrzkościelnych ${ }^{13}$. Na polecenie UdsW z Warszawy dostarczały również regularne i w miarę dokładne ze swojego terenu informacje na temat stanu posiadania domów zakonnych, ich stanu liczbowego, składu społecznego, przestrzegania przepisów państwowych w zakresie tworzenia nowych placówek, powołań zakonnych, zaangażowania zakonników w działalność polityczną, stosunku zakonów z kurią biskupią, realizacji jej dyrektyw, nastawienia biskupów i kurialistów do zakonów, występujących konfliktów i ich podłoża, wprowadzania zmian w regułach i w stylu życia wspólnot, stosunków wewnętrznych, dyscypliny, wystąpień z zakonów, ich rozmiarach i motywach ${ }^{14}$. Władze wyznaniowe były również zainteresowane relacjami, jakie miały zakony z organami administracji państwowej, postawą duchowieństwa za-

${ }^{10}$ AAN, UdsW, sygn.133/17, Pismo Dyrektora UdsW J. Kuberskiego do Dyrektora Wydziału do Spraw Wyznań Urzędu Wojewódzkiego we wszystkich województwach z dnia 31.05.1980 r., k. 3-4.

${ }^{11}$ AAN, UdsW sygn. 133/18, k. 131.

${ }^{12}$ AAN, UdsW, sygn. 133/17, Informacja o stanie posiadania i działalności zgromadzeń zakonnych (męskich i żeńskich) na terenie województwa gorzowskiego wg stanu na dzień 30 czerwca 1980 r, k. 117.

${ }^{13}$ AAN, UdsW, sygn. 133/17, Informacja o stanie posiadania i działalności zakonów i zgromadzeń zakonnych na terenie województwa zielonogórskiego, k. 427-437; tamże, Informacja o stanie posiadania i działalności zgromadzeń zakonnych (męskich i żeńskich) na terenie województwa gorzowskiego wg stanu na dzień 30 czerwca 1980 r., k. 117-132

${ }^{14}$ AAN, UdsW, sygn. 133/18, Schemat informacji na temat stanu posiadania i działalności zakonów i zgromadzeń zakonnych (męskich i żeńskich), k. 5-6. 
konnego i przełożonych zakonnych wobec państwa ludowego, przestrzeganiem założeń społeczno-ustrojowych i prawa państwowego przez domy zakonne ${ }^{15}$.

Powyższe pryncypia, na terenie Środkowego Nadodrza były skierowane wobec zakonników z 11 męskich zakonów i zgromadzeń zakonnych pracujących na tym terenie: księży misjonarzy (m.in. z Gościkowa, Gozdnicy, Gorzowa Wielkopolskiego, Skwierzyny, Słubic, Trzciela); salezjanów (np. Dębna, Warmic, Starego Dworu, Kaławy, Lipek Wielkich, Boleszkowic, Nowogródka Pomorskiego, Różańska, Sarbinowa, Trzcinny); oblatów (z Gorzowa Wielkopolskiego, Obry); kapucynów (z Gorzowa Wielkopolskiego, Nowej Soli); kanoników regularnych (Drezdenka, Niegosławic); werbistów (Templewa): chrystusowców (Piasecznika); jezuitów (Sulęcina); pallotynów (Zieleniewa), redemptorystów (Głogowa), franciszkanów (Wschowy) ${ }^{16}$. W większości przypadków zakonnicy pracowali w placówkach jednoosobowych. Na początku lat 70. XX w. na terenie woj. zielonogórskiego w 14 miejscowościach pracowało 39 księży ze zgromadzenia św. Wincentego á Paulo ${ }^{17}$. Pod koniec lat 70. XX w. na terenie woj. gorzowskiego liczba kapłanów zakonnych oscylowała w granicach 70 zakonników, zaś na terenie woj. zielonogórskiego liczba zakonników wahała się między 46 a 60 osób ${ }^{18}$. W gorzowskim pracowało 7 oblatów, 27 salezjanów, 7 kanoników regularnych, 8 kapucynów, 11 księży misjonarzy, 1 werbista, 1 chrystusowiec, 1 pallotyn i 1 jezuita ${ }^{19}$. Na 101 parafii, 19 było obsługiwanych przez kapłanów zakonnych. W woj. zielonogórskim zakony miały 23 placówki ${ }^{20}$. Dwie placówki zakonne były przy seminariach duchownych: w Obrze - WSD oblatów ( 9 księży, 8 braci i 58 kleryków) i księży misjonarzy w WSD Gościkowie Paradyżu (8 księży misjonarzy), 36 księży zakonnych pracowało w 18 parafiach (11 kapucynów, 15 księży misjonarzy, 7 salezjanów, 2 werbistów, 1 kanonik regularny) i jeden dodatkowo pełnił funkcję kapelana szpitalnego w Zielonej Górze ${ }^{21}$.

${ }^{15}$ Tamże, k. 6.

${ }^{16}$ AAN, sygn. 133/17, Informacja o stanie posiadania i działalności zgromadzeń zakonnych (męskich i żeńskich) na terenie województwa gorzowskiego wg stanu na dzień 30 czerwca 1980 r., k. 117-118; AAN, UdsW, sygn. 133/56, Dane dotyczące rozmieszczenia domów zakonnych w poszczególnych województwach według stanu na 31.12.1976 r., k. 29-31.

${ }^{17}$ APZ, PWRN, sygn. 3247, Pismo Prezydium Wojewódzkiej rady Narodowej w Zielonej Górze do Urzędu do Spraw Wyznań w Warszawie z dnia 16.11.1971 r., k. 101.

${ }^{18}$ AAN, sygn. 133/17, Informacja o stanie posiadania i działalności zgromadzeń zakonnych /męskich i żeńskich/ na terenie województwa gorzowskiego wg. stanu na dzień 30 czerwca 1980 r., k. 118; tamże, sygn. 133/18, Informacja o stanie posiadania i działalności zakonów i zgromadzeń zakonnych na terenie województwa zielonogórskiego, k. 427.

${ }^{19}$ W 1976 r. w woj. gorzowskim było razem wszystkich zakonników: księży 65, braci zakonnych - 5, 1 kleryk, AAN, UdsW, sygn.142/79, Rzymskokatolickie zakony w Polsce (charakterystyka statystyczna na podstawie danych z lat 1971-1975, 20.04.1976 r.), k. 15-16; AAN, sygn. 133/17, Informacja o stanie posiadania i działalności zgromadzeń zakonnych /męskich i żeńskich/na terenie województwa gorzowskiego wg stanu na dzień 30 czerwca 1980 r., k. 117-118.

${ }^{20}$ AAN, UdsW, sygn. 142/79, Zakony męskie w województwach. Zestawienie zbiorcze, k. 1819.

${ }^{21}$ AAN, UdsW, sygn. 133/18, Informacja o stanie posiadania i działalności zakonów i zgromadzeń zakonnych na terenie województwa zielonogórskiego, k. 429. 
W diecezji gorzowskiej, wg danych wydziału wyznań z 1979 r. kapłani zakonni stanowili $33 \%$ ogółu duchowieństwa ${ }^{22}$. Kilku zakonników przeszło do diecezji, zostając administratorami parafii. Władze wojewódzkie dostrzegały malejącą liczbę braci zakonnych, a wzrost liczby księży. Większość księży zakonnych miała pochodzenie robotnicze lub chłopskie. Przeważali zakonnicy w wieku od 40 do 50 lat. Pracownicy wyznaniowi interesowali się także kwestią wykształcenia zakonników. W sprawozdaniach do UdsW podkreślali, że wszyscy zakonnicy mają ukończone zakonne Wyższe Seminarium Duchowne, a niektórzy, np. wykładowcy WSD mieli stopnie naukowe doktora lub tytuł magistra uzyskane na KUL lub $\mathrm{ATK}^{23}$.

Na wspomnianym terenie nie było nowicjatów zakonnych, w związku z tym trudno było funkcjonariuszom wyznaniowym ustalić rozmiary powołań kapłańskich i zakonnych w poszczególnych zakonach. Według ogólnego ich rozeznania wynikało, że powołań z tych terenów było mało - kilka osób ${ }^{24}$. W latach 19751980 odnotowali tylko 4 powołania: 2 do oblatów i 2 do salezjanów. Niemniej jednak uważali, że intensyfikacja działań zakonników w tej kwestii była bardzo różna, począwszy od spotkań z młodzieżą na lekcjach religii, po wspólne wyjazdy i wędrówki oraz rozdawanie im, czy umieszczanie w gablotach kościelnych ulotek powołaniowych ${ }^{25}$.

Działające na tym terenie jedyne zakonne WSD Oblatów w Obrze było opiniowane pozytywnie przez miejscowe władze wyznaniowe - „Działalność zakonnego seminarium w Obrze jest oceniana jako bazująca na przygotowaniu wyniesionym z NSD i rocznego nowicjatu, a formy kształcenia w dużym stopniu opierają się na izolacji alumnów od środowiska. Nie stwierdza się jednak, aby nowo wyświęceni oblaci reprezentowali postawę skrajnie fanatyczną, wrogą wobec władzy i ustroju socjalistycznego. Wręcz przeciwnie, są znani ze swego otwartego stanowiska do różnych spraw i problemów, oraz do lojalnego rozumienia obowiązków wobec państwa i społeczeństwa"26. Jeśli chodzi o pracę księży misjonarzy w WSD diecezjalnym w Gościkowie w omawianym okresie, pracownicy pionu wyznaniowego obserwowali ich stopniowe usuwanie z seminarium, ponieważ według zebranych przez nich opinii metody formacyjne prowadzone przez zakonników „są mocno krytykowane przez księży i nawet biskupów”. Jako

${ }^{22}$ AAN, UdsW, sygn. 142/1, Sprawozdanie z działalności Wydziału Zakonów w Urzędzie do Spraw Wyznań w roku 1979, k. 65.

${ }^{23}$ AAN, sygn. 133/18, Informacja o stanie posiadania i działalności zakonów i zgromadzeń zakonnych na terenie województwa zielonogórskiego, k. 430; AAN, sygn. 133/17, Informacja o stanie posiadania i działalności zgromadzeń zakonnych (męskich i żeńskich) na terenie województwa gorzowskiego wg stanu na dzień 30 czerwca 1980 r., k. 122.

${ }^{24}$ AAN, sygn. 133/18, Informacja o stanie posiadania i działalności zakonów i zgromadzeń zakonnych na terenie województwa zielonogórskiego, k. 429.

${ }^{25}$ AAN, sygn. 133/17, Informacja o stanie posiadania i działalności zgromadzeń zakonnych (męskich i żeńskich) na terenie województwa gorzowskiego wg stanu na dzień 30 czerwca 1980 r., k. 121.

${ }^{26}$ AAN, sygn. 133/18, Informacja o stanie posiadania i działalności zakonów i zgromadzeń zakonnych na terenie województwa zielonogórskiego, k. 429. 
dowód podawali zmianę w ciągu pięciu lat trzech rektorów.

Lokalne władze komunistyczne sporą uwagę poświęcały zachodzącym po Soborze Watykańskim II zmianom życia wewnątrz wspólnot zakonnych na podległym sobie terenie. Dostrzegały przeprowadzane w tym okresie poważne zmiany strukturalno-organizacyjne w zakonach, zwłaszcza ewolucję profilu pracy i zaangażowania zakonników w bezpośredniej pracy duszpasterskiej ${ }^{27}$. Władze wyznaniowe z Gorzowa nie notowały jednak radykalnych zamian w życiu zakonnym wspólnot. Spostrzegły jednak, że ówczesne warunki kulturowe miały wpływ na styl życia księży zakonnych, gdyż w większym stopniu niż w poprzednim okresie, chcieli korzystać „ze zdobyczy cywilizacji”, np. podejmowali starania na wyjazd za granicę w celach turystycznych. Komuniści zauważali również, że młodzi kapłani zakonni hołdowali życiu świeckiemu ${ }^{28}$. Notowali stopniową liberalizację wewnętrznych przepisów zakonnych oraz zachodzącą w zakonach stopniową sekularyzację niektórych dziedzin życia zakonnego, np. zwiększenie swobody osobistej zakonnika, rozluźnienie przepisów i reguły zakonnej. Te zachodzące zmiany starali się wykorzystać na swoją korzyść. Bacznie śledzili również zachodzące w zakonach zmiany w podejściu do ustroju socjalistycznego i władz PRL. $\mathrm{Z}$ tych powyższych względów władze wyznaniowe z Gorzowa Wielkopolskiego i Zielonej Góry, widziały potrzebę bieżącej aktualizacji informacji o zmianach zachodzących w zakonach. W tym też kierunku podejmowały stosownie działania. Starały się monitorować relacje wewnątrzzakonne. Trudno było im jednak ustalić i odpowiednio wykorzystać, rozmiary wewnętrznych tarć i konfliktów. Władze o nich dowiadywały się $\mathrm{w}$ momencie przenosin zakonników z jednego domu do drugiego. Nie notowały wystąpień zakonników z zakonu ${ }^{29}$. Wydział ds. Wyznań udzielał jedynie pomocy występującym zakonnikom z innych województw, osiedlającym się na tym terenie, pomagał w znalezieniu mieszkania, pracy i udzielał pomocy finansowej z Funduszu kościelnego ${ }^{30}$. Pomocy takiej udzielono np. ekspaulinowi, który wystąpił z zakonu i osiadł w woj. zielonogórskim. W podziękowaniu za opiekę, chętnie pisał dla władz komunistycznych różne opracowania dotyczące spraw zakonnych. Interesowała się nim także $\mathrm{SB}^{31}$.

W opinii władz wyznaniowych ogólna sytuacja wśród zakonników na tym terenie była pozytywna. Jako przykład podawały księży misjonarzy, którzy „korzystnie się różnią od diecezjalnych pod względem kultury i obycia, oczywiście

${ }^{27}$ AAN, sygn. 133/17, Informacja o stanie posiadania i działalności zgromadzeń zakonnych /męskich i żeńskich/ na terenie województwa gorzowskiego wg stanu na dzień 30 czerwca 1980 r., k. 122.

${ }^{28}$ Tamże.

${ }^{29}$ AAN, sygn. 133/17, Informacja o stanie posiadania i działalności zgromadzeń zakonnych (męskich i żeńskich) na terenie województwa gorzowskiego wg. stanu na dzień 30 czerwca 1980 r., k. 122.

${ }^{30}$ AAN, sygn. 133/18, Informacja o stanie posiadania i działalności zakonów i zgromadzeń zakonnych na terenie województwa zielonogórskiego, k. 431.

${ }^{31}$ AAN, UdsW, sygn. 133/89, k. 280,659; tamże, Osoby do ewentualnego wykorzystania pisania wspomnień nt. kapłaństwa i pobytu w seminarium (tajne spec. Znaczenia, opr. ppłk, M. Mrozowicz, k. 75. 
poza nielicznymi wyjątkami. Są bardziej przygotowani do dialogu, otwarci na wpływy zewnętrzne. Jest to być może rezultatem większego kontaktu ze światem zewnętrznym z racji różnych wojażów związanych z misjami. Korzystniej różnią się również pod względem moralno-etycznym. Rzadziej trafiają się wśród nich przypadki alkoholizmu i skandale na tle obyczajowo-moralnym. Wynika to bądź z większej dyscypliny życia zbiorowego, które od czasu do czasu spędzają $\mathrm{w}$ domu prowincjalnym $\mathrm{w}$ Krakowie, czy wreszcie $\mathrm{z}$ obawy przed przełożonymi by nie utracić parafii, gdyż mimo wszystko księża ci wolą przebywać w parafii na placówce względnie samodzielnej niż we wspólnym domu pod czujnym okiem przełożonego. Stopień angażowania się księży ze Zgromadzenia św. Wincentego a Paulo do pracy duszpasterskiej i formy ich pracy w zasadzie niczym szczególnym się nie różnią od stopnia zaangażowania kleru diecezjalnego. Nie stwierdza się również w parafiach przez nich obsadzonych większego natężenia uczuć religijnych u wiernych" 32 .

Z tego względu, że na wpomnianym terenie, prawie wszyscy zakonnicy byli zaangażowani w pracy w parafiach, główny kierunek działan lokalnych władz komunistycznych wobec nich, koncentrował się na duszpasterstwie parafialnym. Władze uważały, że parafie prowadzone przez zakonników są na wyższym poziomie $^{33}$. W ich opinii zakonnicy w duszpasterstwie wśród dzieci i młodzieży stosowali bardziej elastyczne metody niż księża diecezjalni ${ }^{34}$. Praca duszpasterska prowadzona przez zakonników, była postrzegana przez nich, jako bardziej efektywna od pracy księży diecezjalnych, ponieważ byli lepiej przygotowani merytorycznie, mieli sprawniejszą organizację wspólnotową i większą umiejętność dostosowania się do lokalnych warunków, lepiej też prowadzili różne przykościelne grupy, które dzięki temu w ich parafiach były liczniejsze i bardziej wyrobione pastoralnie oraz duchowo ${ }^{35}$. Władze uważały, że zakonnicy prowadzili szeroko zakrojoną działalność duszpasterską. Byli widoczni w pracy z młodzieżą i inteligencją (salezjanie, kapucyni, księża misjonarze). Pomagali księżom diecezjalnym w parafiach, szczególnie w okresie świąt Bożego Narodzenia czy Wielkanocy $^{36}$. W latach 70-tych lokalne władze niepokoiło zwłaszcza mocne zaangażowanie zakonników na tym terenie w działalność Ruchu Światło-Życie (był to sposób na kształtowanie postaw religijnych i społecznych młodego pokolenia Polaków, ale też źródło nowych powołań), którzy jednak nie wykraczali poza program diecezjalny. Zakonnicy organizowali wakacyjne akcje oazowe na terenie

${ }^{32}$ AAN, UdsW, sygn. 133/107, Pismo PWRN w Zielonej Górze do UdsW w Warszawie z 16.11.1971 r., k. 71.

${ }^{33}$ AAN, sygn. 133/18, Informacja o stanie posiadania i działalności zakonów i zgromadzeń zakonnych na terenie województwa zielonogórskiego, k.. 432.

${ }^{34}$ AAN, UdsW, sygn. 142/79, k. 254.

${ }^{35}$ AAN, UdsW, sygn. 133/12, Informacja o działalności w Polsce zakonów i zgromadzeń zakonnych, 9.03.1976 r., k. 176; tamże, sygn. 133/61, Informacja o działalności w Polsce zakonów i zgromadzeń zakonnych, 23.10.1975, k. 15-16.

${ }^{36}$ W Duszpasterstwie Akademickim pracował tylko jeden zakonnik w Zielonej Górze. AAN, sygn. 133/17, Informacja o stanie posiadania i działalności zgromadzeń zakonnych (męskich i żeńskich) na terenie województwa gorzowskiego wg. stanu na dzień 30 czerwca 1980 r., k. 123. 
południowej Polski ${ }^{37}$. Oblaci w Gorzowie organizowali comiesięczne spotkania „Przyjaciół misji”. Księża misjonarze w Słubicach urządzali dwa razy w roku wspólne nabożeństwa dla katolików ze Słubic i Frankfurtu ${ }^{38}$. Zakonnicy włączali się także wraz z duchowieństwem diecezjalnym w różne uroczystości kościelne w ramach programu duszpasterskiego. Nadto zakonnicy np. kapucyni angażowali się w działalność charytatywną - pomoc rodzinom wielodzietnym, ubogim i osobom chorym. W tej działalności jak relacjonowały władze wyznaniowe, nie wykraczali poza obręb parafii ${ }^{39}$. Zakonnicy zajmowali się na terenie województwa prowadzeniem rekolekcji i misji parafialnych, które dla wielu były głównym źródłem dochodów ${ }^{40}$. Ogólnie rzecz biorąc, zakonnicy na tym terenie cieszyli się opinią mocno zaangażowanych $\mathrm{w}$ pracę duszpasterską. W parafiach prowadzonych przez zakony władze obserwowały znaczny wzrost życia religijnego, w porównaniu z parafiami diecezjalnym, ale jak np. na terenie woj. zielonogórskiego, władze komunistyczne nie stwierdzały, aby zakonnicy lub parafie przez nich prowadzone, wyróżniały się „organizowaniem różnych form obrzędów kultowych o charakterze widowiskowym" ${ }^{41}$. Jednak jak informowały UdsW w Warszawie, na terenie woj. zielonogórskiego działalność zakonów „nie stanowiła istotnego i liczącego się oddziaływania klerykalnego. Praca ich posiadała zarówno dodatnie jak i ujemne cechy klerykalizacji ludności”. Władze dostrzegały zróżnicowanie podejście, szczególnie młodych zakonników do stawianych im zadań duszpasterskich. Starały się też przeciwdziałać nowym formom działań duszpasterskich zakonników, aby zapobiec „rozszerzaniu się skali klerykalnego oddziaływania na społeczeństwo" ${ }^{2}$. Łudziły się, że „postępujący proces starzenia się zakonników uczyni z nich raczej kłopotliwy problem dla kurii, a ich praca wśród ludzi będzie mało efektywna i przydatna" ${ }^{43}$. Odnotowały jednak na tym polu pewne sukcesy. Działania władz wyznaniowych spowodowały, że zakonnicy w pracy parafialnej starali się prowadzić niezależne działania i wykazywali sporą ostrożność. W połowie lat 70., niektórzy z nich ku zadowoleniu władz państwowych, nie włączali do pracy duszpasterskiej jakichkolwiek działań o charakterze politycznym nieprzychylnych wobec władz ${ }^{44}$. Władze wyznaniowe nie notowały negatywnych wystąpień zakonników i angażowania się ich w szkodliwą działalność polityczną. Wyjątkiem był tu tylko ks. Józef Kutermak, który w licznych wystąpieniach do

${ }^{37} \mathrm{Na}$ przykład moderatorem oazowym w Gorzowie Wielkopolskim był kapucyn o. Zbigniew Jezierski. Tamże.

${ }^{38}$ AAN, sygn. 133/17, Informacja o stanie posiadania i działalności zgromadzeń zakonnych (męskich i żeńskich) na terenie województwa gorzowskiego wg. stanu na dzień 30 czerwca 1980 r., k. 124.

${ }^{39}$ Tamże, k. 125.

${ }^{40}$ AAN, sygn. 133/18, Informacja o stanie posiadania i działalności zakonów i zgromadzeń zakonnych na terenie województwa zielonogórskiego, k. 431.

${ }^{41}$ Tamże, k. 432.

${ }^{42}$ Tamże, k. 437.

${ }^{43}$ Tamże.

${ }^{44}$ Zamiatała, Zakony męskie w polityce władz komunistycznych w Polsce w latach 1945-1989, s. 640 . 
młodzieży oazowej, krytykował ustrój socjalistyczny. Sporadyczne wypadki negatywnych dla władzy wystąpień z ambony spotykały się z szybką reakcją z ich strony ${ }^{45}$.

Tak jak w innych regionach kraju, tak i tutaj, były szczególnie obserwowane i analizowane relacje zakonów z miejscowym biskupem i kurią diecezjalną. $\mathrm{W}$ omawianym okresie w diecezji gorzowskiej biskupem ordynariuszem był ks. Wilhelm Pluta. Jego biskupem pomocniczym był lazarysta ks. Paweł Socha ${ }^{46}$. Według gromadzonych przez wydziały wyznań na ten temat informacji, biskup gorzowski Wilhelma Pluta dążył do tego, aby zakonnicy włączyli się w pełnym zakresie w życie diecezji, jednak specyfika zakonów okazywała się często przeszkodą w realizacji pragnień kurii biskupiej. Wiedzieli, że w opinii bpa W. Pluta zakonnicy nie wywiązywali się dobrze z obowiązków parafialnych i nie odprowadzali ofiar do diecezji, ale tylko do swoich zakonów. Przełożeni zakonni dążyli zaś do uzyskania większej niezależności od biskupów. Władze interesowały się też konfliktami między zakonnikami, a księżmi diecezjalnymi zwłaszcza gdy chodziło o podział administracyjny parafii ${ }^{47}$. Władze wyznaniowe zdobyły informacje, że w diecezji księża zakonni w duszpasterstwie parafialnym byli traktowani jako zło konieczne, głównie z uwagi na brak księży diecezjalnych, a obsadzanie kolejnych parafii zakonnikami, oraz ekszakonnikami, którzy przeszli do diecezji, uważali za sytuację przejściową. Wiedziały, że kuria chętnie by się pozbyła zakonników z parafii, gdyby miała wystarczającą liczbę księży diecezjalnych ${ }^{48}$. Z pewnych źródeł miały informację, że wśród duchowieństwa panowała opinia, że biskup będzie się pozbywał zakonników w miarę wzrostu liczby księży diecezjalnych. Główną przyczyną tych nieporozumień, jak sądziły, są kwestie finansowe, gdyż zakonnicy część pieniędzy zamiast do diecezji oddawali swojemu zakonowi. Duchowieństwo diecezjalne zazdrościło zakonnikom, że administrowali tzw. lepszymi parafiami. Te opinie duchowieństwa diecezjalnego nie zawsze miały pokrycie $\mathrm{w}$ faktach. $\mathrm{Z}$ informacji, jakie posiadały władze wyznaniowe, $\mathrm{np}$. w przypadku księży misjonarzy: „Na 14 parafii administrowanych przez lazarystów na terenie woj. zielonogórskiego tylko 3 były zdaniem władz intratne, reszta to średnie lub „chude" ${ }^{\text {" }}$. Komuniści z terenu Środkowego Nadodrza byli poinformowani, że biskupa i kurię diecezjalną denerwowało pomijanie ich i nie informowanie przez zakonników o załatwianiu różnych spraw z urzędami państwowymi. Nadto zakonnicy w niektórych przypadkach, mało angażowali się, mimo nakazów kurii, w sprawę remontów budynków sakralnych, czy w pracę z poszczególnymi

${ }^{45}$ AAN, sygn. 133/17, Informacja o stanie posiadania i działalności zgromadzeń zakonnych (męskich i żeńskich) na terenie województwa gorzowskiego wg stanu na dzień 30 czerwca 1980 r., k. 125 .

${ }^{46}$ Tamże.

${ }^{47}$ Tamże.

48 AAN, UdsW, sygn. 133/107, Pismo PWRN w Zielonej Górze do UdsW w Warszawie z 16.11.1971 r. k. 71.

${ }^{49}$ Tamże, k. 70-71. 
środowiskami parafialnymi ${ }^{50}$. Wiedzieli, że na tle stosunku zakonników do właściwego utrzymania obiektów sakralnych oraz innych kwestii, powstawały często konflikty z kurią diecezjalną, co niekiedy doprowadzało do odwołania zakonnika z funkcji administratora parafii ${ }^{51}$. Najgłośniejszy konflikt w tym okresie, jaki zanotowali wyznaniowcy, był między księżmi misjonarzami kierującymi WSD a biskupem w Gościkowie. Źródłem tego konfliktu było szukanie przyczyn słabych wyników nauczania kleryków oraz liczne ich wydalenia z Wyższego Seminarium Duchownego. Zarzucano lazarystom również niski poziom wykształcenia księży, którzy ukończyli seminarium. Biskup zamierzał usunąć wszystkich zakonników z seminarium, jednak ze względu na brak innych wykładowców, pozbawił ich jedynie stanowisk kierowniczych i usunął kilku najbardziej mu nieodpowiadających. Mimo tych posunięć, poziom seminarium się nie podniósł i nadal były narzekania na niski poziom wiedzy młodych księży. Pracownicy pionu wyznaniowego posiadali także informacje o innych konfliktach i nieporozumieniach między tymi zakonnikami, a kurią gorzowską. Jedną z przyczyn - jak podawali w piśmie do UdsW w Warszawie - upatrywali w tym, że „Dochodzi do tego również fakt o bardzo kapitalnym dla kurii znaczeniu a mianowicie - księża ze Zgromadzenia św. Wincentego á Paulo są bardziej niezależni od księży diecezjalnych, nie są inkardynowani do diecezji i z tego względu mogą sobie pozwolić na większą samodzielność, są mniej serwilistyczni niż księża diecezjalni. Księża ci są bardziej związani ze Zgromadzeniem niż z kurią, mają przeświadczenie o tym, że Zgromadzenie zawsze im zapewni „kawałek chleba”, stąd „łaska biskupia" nie jest u nich w takiej cenie jak u księży diecezjalnych. Owszem są posłuszni wobec biskupa na terenie jego diecezji, ale tylko w zakresie jurysdykcji kościelnej ale nic ponadto, gdy z praktyki codziennej wiadomo, że w kurii cenieni są księża, którzy lubią świadczyć materialnie ponad obowiązkową konieczność. Równocześnie ta niezależna postawa cechuje ich nawet w życiu codziennym, uwidacznia się nawet w stroju. Księża z tego Zgromadzenia rzadziej występują na zewnątrz - poza kościołem - w sutannie niż księża diecezjalni" ${ }^{52}$.

Innym powodem antagonizmów między zakonnikami, a kurią diecezjalną, było utrudnianie przez tę ostatnią przejęcia nieruchomości na rzecz zgromadzenia zakonnego. Zakonnicy pomni swych zasług dla tej diecezji chcieli w parafiach obsługiwanych przez siebie, przejąc nieruchomości na rzecz zgromadzenia zakonnego, kuria biskupia natomiast, chciała przekazania ich na rzecz parafii. Powodowało to rozgoryczenie, np. wśród księży misjonarzy, narastała wzajemna niechęć, źle zresztą maskowana na zewnątrz ${ }^{53}$. Wszelkie zebrane informacje odnośnie do zakonów i zgromadzeń zakonnych, służyły aparatowi państwowemu do opracowywania i podejmowania działań, służących do pogłębienia podziałów i konfliktów między duchowieństwem diecezjalnym i zakonnym. Wydział wyznań dążył

${ }^{50}$ AAN, sygn. 133/18, Informacja o stanie posiadania i działalności zakonów i zgromadzeń zakonnych na terenie województwa zielonogórskiego, k. 433.

${ }^{51}$ Tamże, k. 435.

${ }^{52}$ AAN, UdsW, sygn. 133/107, Pismo PWRN w Zielonej Górze do UdsW w Warszawie z 16.11.1971 r. k. 70-71.

${ }^{53}$ Tamże, k. 71. 
także do osłabienia wpływów biskupa na zakony i zgromadzenia zakonne. Wydziały ds. Wyznań PWRN, w pracy z przełożonymi zakonnymi usiłowały uniezależnić zakony od linii postępowania kurii biskupiej. Starały się, aby zakonnicy unikali pośrednictwa kurii diecezjalnej w kontaktach z władzami państwowymi i swoje sprawy załatwiali bezpośrednio w urzędach państwowych. Władze dążyły do pogłębiania izolacji między duchowieństwem diecezjalnym i zakonnym ${ }^{54}$. Starały się umacniać w społeczeństwie pozycję kapłanów zakonnych kosztem diecezjalnych ${ }^{55}$.

Relacje zakonów z władzami państwowymi, zdaniem władz wyznaniowych, układały się poprawnie ${ }^{56}$. Zakony na tym terenie wyróżniały się pozytywnym stosunkiem do władzy komunistycznej i w zasadzie nie przekraczały przepisów państwowych. Przełożeni lokalni utrzymywali kontakty z wydziałem wyznań i z innymi terenowymi organami władzy państwowej. Odwiedzali siedzibę WdsW przy różnych okazjach. Większość z nich była pozytywnie ustosunkowana do państwa ludowego i władz, co wyrażało się w częstych rozmowach z komunistami.

Naczelnicy gmin, pod naciskiem UdsW, nawiązywali kontakty z przełożonymi placówek zakonnych, żeby zdobyć poparcie zakonów dla inicjatyw lokalnych zmierzających do rozwiązywania ważnych potrzeb społecznych. Władze wyznaniowe zwracały baczną uwagę na udział zakonników w wyborach do Rad Narodowych i do Sejmu, cieszyły się z dużego udziału duchownych w wyborach ${ }^{57}$. One też lub urzędnicy Wydziału ds. Wyznań, organizowały spotkania na tematy społeczno-gospodarcze z zakonnikami ${ }^{58}$.

Te pozytywne dla władz państwowych postawy zakonników wynikały z realizowanej od połowy lat 60. polityki podporządkowania i lojalizacji zakonów. W urzeczywistnianiu tej strategii, Wydziały ds. Wyznań z terenu Srodkowego Nadodrza posługiwały się opracowanymi na początku lat 70. przez wydział Zakonów w UdsW, następującymi kryteriami lojalności zakonów wobec władz państwowych:

1) Załatwienie wszelkich spraw dot. placówek i osób zakonnych bezpośrednio z właściwymi organami administracji państwowej, bez pośrednictwa Episkopatu;

2) Uczestnictwo w wyborach do Sejmu i rad narodowych, głosowanie bez skreśleń przy jednoczesnym niewykorzystywaniu kampanii wyborczych do wywierania nacisku na władze państwowe;

3) Działanie we wszelkich sprawach drogą legalną z poszanowaniem obowiązujących przepisów państwowych;

${ }^{54}$ AAN, sygn. 133/17, Informacja o stanie posiadania i działalności zgromadzeń zakonnych (męskich i żeńskich) na terenie województwa gorzowskiego wg stanu na dzień 30 czerwca 1980 r., k. 130

${ }^{55}$ Tamże, k. 131.

${ }^{56}$ AAN, sygn. 133/18, Informacja o stanie posiadania i działalności zakonów i zgromadzeń zakonnych na terenie województwa zielonogórskiego, k 434

${ }^{57}$ AAN, UdsW, sygn. 133/18, k. 26.

${ }^{58}$ AAN, sygn. 133/17, Informacja o stanie posiadania i działalności zgromadzeń zakonnych (męskich i żeńskich) na terenie województwa gorzowskiego wg stanu na dzień 30 czerwca 1980 r., k. 126. 
4) W przypadkach konfliktowych dążenie do załatwiania spraw spornych w sposób ugodowy, bez odwoływania się do opinii środowisk katolickich i do Episkopatu (m.in. nieinspirowanie pisemnych i ustnych petycji do władz);

5) Dopuszczanie do wizytacji placówek zakonnych (domów zakonnych, WSD, NSD), udzielanie w trakcie tych wizytacji rzetelnych informacji oraz stosowanie do zaleceń i uwag powizytacyjnych;

6) Niewłączanie do działalności duszpasterskiej negatywnych akcentów politycznych (m.in. poprzez pomijanie szkodliwych fragmentów listów pasterskich i innych enuncjacji Episkopatu, nieuczestniczenie w różnych kościelnych kampaniach propagandowych wymienionych przeciwko władzom państwowym itp.);

7) Oddziaływanie na wiernych zarówno w kazaniach jak i kontaktach osobistych oraz przez wydawnictwa na kształtowanie właściwej postawy obywatelskiej (rzetelnego stosunku do pracy, własności społecznej, inspirowanie czynów społecznych na rzecz własnego środowiska itp.);

8) Uczestniczenie w spotkaniach organizowanych przez władze państwowe (dot. administratorów parafii zakonnych lub administrowanych przez zakony, prowincjałów, księży zakonnych pracujących wśród Polonii $)^{59}$.

Zaostrzenie lub złagodzenie kursu wobec zakonów uzależniały od zachowania i postawy zakonników w określonym czasie. W tych warunkach zakonni proboszczowie byli podatni na uleganie presji władz państwowych.

Zdaniem władz komunistycznych polityka lojalizacji zakonów została zrealizowana w dużym stopniu już na początku lat 70., dzięki zastosowaniu przez władze elastycznej strategii postępowania wobec zakonów. Zakonnicy wyraźnie zmienili swoje negatywne stanowisko do władz państwowych na lojalne lub neutralne. Przyjęli pragmatyczną postawę, uważając, że tylko przez dostosowanie się do zarządzeń władz państwowych można odnieść jakieś wymierne korzyści ${ }^{60}$. W związku z tym nie kwestionowali na ogół nadzoru państwowego nad zakonem, brali udział w wyborach do Sejmu i Rad Narodowych i zachęcali do tego wiernych w parafiach, w których pracowali ${ }^{61}$. Komuniści mieli jednak świadomość, że przeważała jednak bierna postawa zakonników wobec władz państwowych. Mogli się jednak poszczycić, że dzięki prowadzonym działaniom lojalizacyjnym, większość zakonników akceptowała założenia ustrojowe PRL i wykazywała się „wysoką dyscypliną obywatelską”, a także należytym wywiązywaniem się przez nich ze zobowiązań finansowych wobec państwa, braniem udziału w wyborach i przestrzeganiem przepisów państwowych. Pewną jednak bolączką było dla władzy ograniczanie się zakonników w kontaktach z władzami wyznaniowymi do koniecznego minimum, wynikającego $\mathrm{z}$ potrzeby załatwienia spraw. $\mathrm{W}$ ramach pracy z zakonami, naczelnicy gminy lub urzędnicy Wydziału ds. Wyznań dodat-

${ }^{59}$ AAN, UdsW, sygn. 142/1, Komentarz do informacji o aktualnej sytuacji i zadaniach w pracy z zakonami, k. 154-155

${ }^{60}$ AAN, UdsW, sygn. 133/475, Sprawozdanie z pracy działu zakonów i zgromadzeń zakonnych męskich w 1971 roku z 18 XII 1971 roku, k. 39.

${ }^{61}$ Zamiatała, Zakony męskie w polityce władz komunistycznych w Polsce w latach 1945-1989, s. 198 
kowo organizowali z zakonnikami spotkania na tematy społeczno-gospodarcze ${ }^{62}$. Kontynuowano wobec zakonów „elastyczną politykę”, czyli reglamentowanie rozmaitych ułatwień (tak jak w poprzedniej dekadzie: ulgi podatkowe, udogodnienia paszportowo-dewizowe, udogodnienia związane $\mathrm{z}$ budownictwem sakralnym, działalnością gospodarczą). Starano się też w miarę możliwości załatwić uznane za słuszne i wymagające realizacji postulaty zakonów ${ }^{63}$.

Zakonnicy w zamian, deklarowali oficjalnie poparcie dla polityki władzy ludowej, wywiązywali się z obowiązków wykonywania przepisów państwowych, unikali jakichkolwiek konfliktów z władzami. Dzięki czemu, Wdziały ds. wyznań rzadko już napotykały na trudności w wypełnianiu przez placówki zakonne zarządzeń państwowych i nie odnotowywały przypadków negatywnych wystąpień duchownych z ambony, skierowanych przeciwko władzy. Przełożeni domów zakonnych unikali również jakichkolwiek konfliktów z władzami państwowymi, składali sprawozdania z działalności prowadzonych przez nich punktów katechetycznych przy klasztorach i kościołach zakonnych, a także na bieżąco płacili podatki od nieruchomości. Nie wnosili również zastrzeżeń, co do wizytacji domów zakonnych przez władze państwowe i bez problemów udzielali informacji na temat działalności domu zakonnego, składu osobowego wspólnoty, nie unikali rozmów na tematy społeczno-gospodarcze, czy dotyczące relacji państwo-Kościół.

Wojewódzkie władze wyznaniowe monitorowały działania zakonów, starając się wychwycić przejawy „negatywnego stosunku zakonów do władzy ludowej”, który - ich zdaniem - wyrażał się przede wszystkim w „nadużywaniu ambony dla celów politycznych, organizowaniu nielegalnych zbiórek i omijaniu obowiązujących przepisów państwowych" ${ }^{64}$. Przy różnych okazjach nakłaniały zakonników do zaniechania lub niepodejmowania tych praktyk. Efektem tych zabiegów był pożądany przez komunistów dystans kapłanów zakonnych wobec wydarzeń politycznych. Zakonnicy zajmowali postawę wyczekującą, np. wobec wydarzeń grudniowych $1970 \mathrm{r}$. i czerwcowych z $1976 \mathrm{r}$. Unikali też w tym czasie podsycania, czy zaogniania nastrojów społecznych, ale też nie było z ich strony uspokajającego wpływu na społeczeństwo. Władze państwowe interesowały się opiniami zakonników dotyczących zmian w kierownictwie partii i rządu w grudniu $1970 \mathrm{r}$. Jak donosili urzędnicy lokalnego Wydziału wyznań do UdsW w Warszawie, duchowieństwo zakonne przyjęło te zmiany z zadowoleniem, a zapowiedź normalizacji stosunków państwa z Kościołem uznawali za ,jedyne mądre wyjście" ${ }^{65}$. Według ich rozeznania zakonnicy wyrażali nadzieję, że nowa ekipa zmieni stosu-

${ }^{62}$ AAN, sygn. 133/17, Informacja o stanie posiadania i działalności zgromadzeń zakonnych (męskich i żeńskich) na terenie województwa gorzowskiego wg stanu na dzień 30 czerwca 1980 r., k. 126.

${ }^{63}$ AAN, sygn. 133/18, Informacja o stanie posiadania i działalności zakonów i zgromadzeń zakonnych na terenie województwa zielonogórskiego, $\mathrm{k} 434$.

${ }^{64}$ Zamiatała, Zakony męskie w polityce władz komunistycznych w Polsce w latach 1945-1989, s. 173.

${ }^{65}$ AAN, UdsW, sygn. 133/60, Działalność zakonów i zgromadzeń zakonnych męskich, k.132142. 
nek państwa do Kościoła i będzie on lepszy niż za czasów Władysława Gomułki i nastąpi wreszcie uregulowanie stosunków między państwem a Kościołem. Z zadowoleniem przyjęli zapowiedź nadania praw majątkowych Kościołowi rzymskokatolickiemu na Ziemiach Zachodnich i Północnych, udzielania zezwoleń na budowę kościołów, cofnięcia podwyżek cen ${ }^{66}$.

Władze wyznaniowe w pierwszej połowie lat 70 . stwierdzały na ogół, że postawa zakonów wobec władz państwowych była nienaganna. Zakonnicy nie podejmowali w tym czasie żadnych działań niezgodnych z interesem państwa i władz PRL. Wydziały szczyciły się niemal całkowitym wyeliminowaniem krytycznych uwag zakonników, na które pozwalali sobie w czasie homilii, co przez wiele lat traktowano jako sprawę priorytetową ${ }^{67}$. Zdaniem pracowników pionu wyznaniowego nie było negatywnych wystąpień zakonników z ambony, gdyż lokalne władze nie notowały wśród zakonników manifestowania postaw antypaństwo$w \mathrm{ych}^{68}$. Zakonnicy powstrzymywali się od udziału w pozareligijnej, a zwłaszcza politycznej działalności, nie wygłaszali kazań wrogich przeciwko państwu. Mimo tego, funkcjonariusze aparatu wyznaniowego wciąż pilnowali realizacji wytycznych UdsW dotyczących powstrzymania zakonników od działalności politycznej i pełnego poszanowania ustroju socjalistycznego oraz obowiązujących przepisów państwowych. Starali się wnikliwiej poznawać stopień szczerości deklaracji lojalności składanych władzom państwowym. Komuniści domagali się od zakonów konkretnych znaków lojalności wobec państwa, a nie tylko ogólników. Przez całą dekadę realizowali również taktykę dezintegracji zakonów.

W ramach prowadzenia systematycznego nadzoru nad zakonami, ich działalnością i lojalizacją, Wydziały ds. Wyznań przeprowadzały rozmowy indywidualne $\mathrm{z}$ przedstawicielami zakonów ${ }^{69}$. Były one traktowane przez urzędników wyznaniowych jako jedna $\mathrm{z}$ form pracy w podporządkowaniu zakonów władzy państwowej. Stanowiły ważny instrument oddziaływania na zakonników ${ }^{70}$. Wydziały wojewódzkie na polecenie Urzędu ds. Wyznań starały się przeprowadzać częste rozmowy z przełożonymi domów zakonnych. Dotyczyły one na ogół takich zagadnień jak: polityki społeczno-gospodarczej państwa, powiatu, regionu, stosunków państwa z Kościołem, spraw związanych z działalnością i potrzebami zakonników czy postulatami WdsW. W grudniu 1973 r. np. pracownicy Wydziału Wyznań otrzymali z UdsW w Warszawie tematy do rozmów z duchowieństwem ${ }^{71}$. Dotykały one takich kwestii jak: wizyta Ministra Spraw Zagranicznych S. Ol-

${ }^{66}$ Tamże, k. 135 .

${ }^{67}$ AAN, UdsW, sygn. 133/18, k. 38.

${ }^{68}$ AAN, sygn. 133/17, Informacja o stanie posiadania i działalności zgromadzeń zakonnych (męskich i żeńskich) na terenie województwa gorzowskiego wg stanu na dzień 30 czerwca 1980 r., k. 130.

${ }^{69}$ AAN, UdsW, sygn. 125/64, Pismo Mieczysława Żywickiego Kierownika Wojewódzkiego Wydziału do Spaw Wyznań do Urzędu do Spraw Wyznań w Warszawie z 19.05.1973 r., k. 268-273.

${ }^{70}$ AAN, sygn. 125/64, Notatka w sprawie ożywienia kontaktów z duchowieństwem, k. 1-8.

${ }^{71}$ AAN, UdsW, sygn. 125/64, Pismo dr Aleksandra Merkera do Kierownika Wydziału ds. Wyznań Prezydium Wojewódzkiej Rady Narodowej z 3.12.1973 r., k.114; tamże, Tezy do rozmów z klerem z 30.11.1973 r., k. 116-117. 
szowskiego w Watykanie, pozytywne zainteresowanie się Stolicy Apostolskiej osiągnięciami rządu PRL oraz jej pragnienie unormowania relacji z władzami w Warszawie, któremu jednak przeszkadza polski Episkopat. W tej ostatniej sprawie zamierzano wmówić potencjalnym rozmówcom, że „istnieje różnica w postawach między Watykanem, a Episkopatem polskim odnośnie normalizacji wzajemnych stosunków [z PRL - D.Z.]"72. Pracownicy Wydziału Wyznań podejmowali również rozmowy z przełożonymi prowincjalnymi na temat ich podwładnych pracujących na tym terenie, np. przeprowadzili rozmowę $\mathrm{z}$ wizytatorem księży misjonarzy o konieczności przeniesienia ks. Józefa Kutermaka poza województwo zielonogórskie. W wyniku rozmów, władze uzyskiwały brakujące informacje statystyczne dotyczące domów zakonnych, wstępne rozeznanie w ich działalności zewnętrznej, wewnątrz placówek, lepsze poznanie przełożonych ${ }^{73}$. Rozmowy z zakonnikami - jak stwierdzały władze wyznaniowe w sprawozdaniu do UdsW w Warszawie - miały pozytywny wpływ na zakonników i ich stosunek do władz państwowych. Okazały się one dla władz państwowych - „skuteczniejszą formą oddziaływania na duchowieństwo, niż sankcje karno-administracyjne czy też sądowe. Represyjne metody bowiem hierarchia przedstawiała jako przejaw walki Państwa z Kościołem, zniechęcając księży o chwiejnej postawie wobec władzy ludowej"74. Tylko nieliczni zakonnicy wyrażali dezaprobatę i niechęć do rozmów z przedstawicielami władz państwowych, unikając tych rozmów lub sprowadzając ich tematykę do spraw mało istotnych ${ }^{75}$. Większość księży zakonnych, jednak ceniła sobie kontakty z władzami państwowymi, a nawet często je inicjowała i przedstawiała różne sprawy - jak to określały - „we właściwym naświetleniu"76. W latach 1971-1973 władze odpowiedzialne za realizację polityki wyznaniowej w regionie, rocznie przeprowadzały indywidualne rozmowy z kilkudziesięcioma zakonnikami ${ }^{77}$. W czasie rozmów w wydziale wyznań przełożeni deklarowali pełną lojalność wobec państwa i pokazywali to w praktyce.

Władze wyznaniowe przeprowadzały rozmowy z zakonnikami przy okazji ich starań o wyjazd za granicę czy innych kwestii dotyczących spraw osobistych. Z kapłanami zakonnymi, którzy prowadzili parafie, rozmawiali także naczelnicy miast i gmin. Zakonnicy brali też udział w spotkaniach i rozmowach z wojewodami, których treścią były najczęściej sprawy dotyczące rozwoju społeczno-gospodarczego województwa i kraju. W czasie tych rozmów zakonnicy deklarowali pomoc

${ }^{72}$ Tamże.

${ }^{73}$ AAN, UdsW, sygn. 133/12, Eryk Sztekker, Charakterystyka niektórych problemów wyznaniowych i posumowanie wyników prac wykonanych w roku 1979, k. 242.

${ }^{74}$ AAN, sygn.125/64, Notatka w sprawie ożywienia kontaktów z duchowieństwem, k. 2-3.

${ }^{75}$ AAN, sygn. 133/18, Informacja o stanie posiadania i działalności zakonów i zgromadzeń zakonnych na terenie województwa zielonogórskiego, k 434; tamże, sygn. 133/12, Eryk Sztekker, Charakterystyka niektórych problemów wyznaniowych i posumowanie wyników prac wykonanych w roku 1979, k. 242.

${ }^{76}$ AAN, sygn. 133/18, Informacja o stanie posiadania i działalności zakonów i zgromadzeń zakonnych na terenie województwa zielonogórskiego, $\mathrm{k} 434$.

77 AAN, UdsW, sygn.125/64, Pismo Mieczysława Żywickiego Kierownika Wojewódzkiego Wydziału do Spaw Wyznań do Urzędu do Spraw Wyznań w Warszawie z 19.05.1973 r., k. 270. 
w zwalczaniu ujemnych zjawisk społecznych, takich jak alkoholizm, wandalizm, brak gospodarności, nieposzanowanie mienia społecznego ${ }^{78}$. W czasie rozmów indywidualnych władze wyznaniowe, poza konkretnymi sprawami, starały się poznać, jaki jest stosunek pojedynczych zakonników do PRL, a także przybliżyć im osiągnięcia społeczne i gospodarcze ludowej ojczyzny. Rozmówcy zgłaszali się na zaproszenie, zachowywali się poprawnie i grzecznie, mówili o obawach przed utratą posady i powrotem do domu macierzystego. W czasie tych rozmów pracownicy wyznaniowi dowiadywali się o konfliktach zakonników z kurią gorzowską, np. w czasie rozmów w wydziale ds. wyznań kanonik regularny ks. Stefan Zagrodzki z Drezdenka żalił się, że „kuria chce go całkowicie unicestwić”. Podobne żale w Wydziale ds. Wyznań artykułował ks. Andrzej Balicki lazarysta pracujący w Żaganiu ${ }^{79}$.

Kontakty zakonników z władzami państwowymi nie były jednak tak częste, jakby sobie tego komuniści życzyli. Zakonnicy thumaczyli się w tym względzie zachowaniem rozsądnej granicy $\mathrm{w}$ tych spotkaniach, gdyż podlegali potrójnej władzy - własnym przełożonym zakonnym, biskupowi i władzom państwowym ${ }^{80}$. Bali się bowiem powrotu do klasztoru, gdyż woleli pozostać i pracować na placówkach parafialnych, dlatego starali się zachowywać ostrożność w kontaktach z władzami państwowymi. Wydział zielonogórski i gorzowski organizował każdego roku również ogólne, zbiorowe spotkania dla duchowieństwa diecezjalnego i zakonnego ${ }^{81}$. W czasie tych spotkań informowano uczestników o realizacji planu społeczno-gospodarczego, o osiągnięciach i problemach społecznych regionu. Władze notowały na tych spotkaniach chętne włączanie się zakonników do dyskusji, którzy zgłaszali też swoje postulaty głównie dotyczące porządkowania cmentarzy, naprawy dróg czy działań zmierzających do poprawy estetyki i stanu sanitarnego $\mathrm{wsi}^{82}$.

Niezależnie od organizowanych spotkań urzędnicy wyznaniowi udawali się do zakonników w ich miejscu zamieszkania na spotkanie, wykorzystując do rozmowy każdy nadający się pretekst ${ }^{83}$. Zakonnicy reagowali pozytywnie na wszelkie zaproszenia, czy wezwania ze strony władz państwowych. Władze wyznaniowe szczyciły się, że wskutek systematycznej pracy wydziału zacieśniły się relacje między zakonnikami, a organami władzy państwowej. Zauważyły, że najbardziej

${ }^{78}$ AAN, UdsW, sygn. 133/18, k. 396.

${ }^{79}$ AAN, UdsW, sygn. 133/14, Podstawowe tezy i oceny przebiegu rozmów z przełożonymi domów zakonów męskich, k. 99.

${ }^{80}$ AAN, sygn. 133/17, Informacja o stanie posiadania i działalności zgromadzeń zakonnych (męskich i żeńskich) na terenie województwa gorzowskiego wg stanu na dzień 30 czerwca 1980 r., k. 126.

${ }^{81}$ AAN, UdsW, sygn. 125/64, Informacja z 23.06.1973 r., k. 88-89.

${ }^{82}$ AAN, sygn. 133/17, Informacja o stanie posiadania i działalności zgromadzeń zakonnych /męskich i żeńskich/ na terenie województwa gorzowskiego wg stanu na dzień 30 czerwca 1980 r., k. 128; tamże, sygn. 125/62, Ocena pracy prezydiów rad narodowych z biskupami i klerem, k. 41-42.

${ }^{83}$ AAN, sygn. 133/17, Informacja o stanie posiadania i działalności zgromadzeń zakonnych (męskich i żeńskich) na terenie województwa gorzowskiego wg. stanu na dzień 30 czerwca 1980 r., k. 128. 
życzliwe nastawienie do zarządzeń państwowych mieli proboszczowie zakonni na parafiach jednoosobowych. Według ich opinii, ulegali oni szybkiemu zeświecczeniu i w trosce o utrzymanie się na parafii, starali się utrzymać ze wszystkimi, tj. z władzami państwowymi, zakonnymi i diecezjalnymi poprawne relacje. Oni też, po kilku latach pracy na samodzielnej parafii, unikali potencjalnych konfliktowych sytuacji z władzami państwowymi, gdyż bali się utraty parafii i powrotu do klasztoru. Ci księża uczestniczyli w zbiorowych zebraniach księży, organizowanych przez przewodniczących Powiatowych Rad Narodowych, składali też sprawozdania z działalności punktów katechetycznych. Nie chcieli zadrażniać stosunków z państwem, więc nie podejmowali inicjatyw duszpasterskich budzących zastrzeżenia natury politycznej ${ }^{84}$. Najbardziej podatni na sugestie władz państwowych byli proboszczowie zakonni, którzy starali się unikać jakichkolwiek zadrażnień. Mimo zakazu biskupów część z nich prowadziła księgę inwentarzową i miała zarejestrowany punkt katechetyczny, składała też sprawozdania.

Obok rozmów z zakonnikami ważną formą nadzoru państwa nad zakonami były wizytacje domów zakonnych. Dla wojewódzkich Wydziałów ds. Wyznań $\mathrm{z}$ omawianego regionu Polski, były to bezpośrednie i cenne kontakty z poszczególnymi zakonami. Zostały one zobligowane przez UdsW do ich systematycznego przeprowadzania. Miały też obowiązek na ich podstawie opracowywać analizy odnośnie do działalności zakonów na swoim terenie. Uzyskane informacje w czasie wizytacji, pozwalały pracownikom działu wyznaniowego lepiej poznać sytuację panującą w danym domu zakonnym, jego faktyczną działalność, stan posiadania i dochody placówek zakonnych, postawy ich członków, wewnętrzne konflikty i animozje, stosunek do hierarchii kościelnej i zakonnej. Miały też bezpośrednią możliwość wpływania na właściwą postawę przełożonych wspólnot i zakonników wobec władz państwowych. Wizytacje domów zakonnych miały duże znaczenie dla pracy wydziałów wyznań, ponieważ dostarczały materiał służący do opracowania odpowiedniej polityki komunistów wobec zakonów ${ }^{85}$. Ułatwiały władzom państwowym wyrobieniu sobie poglądu na temat zakonników na tym terenie. Służyły one także wydziałom wyznań do przeciwdziałania naruszeniu przepisów państwowych przez zakony, ograniczaniu działalności zakonów, zapobieganiu działalności ,antypaństwowej”, do której zaliczono prowadzenie duszpasterstwa wśród inteligencji i młodzieży. Tematyka rozmów wizytatorów z zakonnikami w czasie wizytacji dotyczyła zarówno spraw ogólnych o charakterze państwowym, jak i też problemów funkcjonowania domów zakonnych na tym terenie, posiadaniu przez nie środków, form działania i postulatów zgłaszanych władzom państwowym ${ }^{86}$. Wizytacje pozwalały władzom wyznaniowym różnicować decyzje w sprawach interesujących zakony w zależności od stopnia lojalności i wypełniania przepisów państwowych ${ }^{87}$. Władze wyznaniowe w ich trakcie wyszuki-

${ }^{84}$ AAN, UdsW, 133/60, Działalność zakonów i zgromadzeń zakonnych męskich, k. 157.

${ }^{85}$ AAN, UdsW, sygn. 133/17, k. 121.

${ }^{86}$ AAN, sygn. 133/18, Informacja o stanie posiadania i działalności zakonów i zgromadzeń zakonnych na terenie województwa zielonogórskiego, k. 434.

${ }^{87}$ AAN, UdsW, sygn. 142/1, Informacja o aktualnej sytuacji i zasadach w pracy z zakonami, k. 237. 
wały zakonników gotowych do układania się z władzami państwowymi. Bardzo dobre relacje układały się między władzami wyznaniowymi a oblatami w Obrze, gdzie zakonnicy szczerze informowali władze o sytuacji na swoim terenie oraz o zamierzeniach i inicjatywach ${ }^{88}$. Zdaniem władz, placówki zakonne w tej dekadzie nie stwarzały władzom sytuacji konfliktowych w postaci naruszeń obowiązującego prawa ${ }^{89}$. Nieliczne zaś odstępstwa w tych sprawach zakonników wynikały jedynie z nacisków kurii biskupiej czy biskupa.

Władze na bazie wizytacji i rozmów dostrzegły, że zakonników „,cechuje daleko posunięty realizm w ocenie sytuacji i wynikająca stąd dążność do stabilizacji swojego bytu w obecnych warunkach ustrojowych" oraz unikanie działań mogących ich postawić w otwartym konflikcie z władzami państwowymi ${ }^{90}$. W $1970 \mathrm{r}$. w woj. zielonogórskim wydział wyznań zwizytował zaledwie cztery placówki zakonne $^{91}$. W następnych latach WdsW postanowił co dwa lata przeprowadzać wizytację domu zakonnego. W wyniku tych planów na koniec dekady jak podawali w sprawozdaniach do UdsW w Warszawie mieli 80\% domów zwizytowanych.

Istotnym wydarzeniem $w$ omawianej dekadzie, mającym duży wpływ na relacje władz państwowych z zakonami i zgromadzeniami zakonnymi, była sprawa uregulowania na nowo statusu własności majątku Kościoła na Ziemiach Zachodnich. W czerwcu 1971 r. sejm uchwalił ustawę O przejściu na osoby prawne Kościoła rzymsko-katolickiego oraz innych kościołów i zwiazków wyznaniowych własności niektórych nieruchomości położonych na Ziemiach Zachodnich Pótnoc$n y c h^{92}$. W czasie uregulowania spraw własności kościelnej na Ziemiach Zachodnich i Północnych ustalono, że zakony, prowincje zakonne, domy zakonne i WSD zakonne są osobami prawnymi i może przejść na ich własność nieruchomość. W wyniku wprowadzenia w życie tej ustawy, władze komunistyczne podjęły szereg decyzji pozytywnych w sprawach majątkowych zakonów na terenie Srodkowego Nadodrza. Decyzje te były podjęte na przekór kurii diecezjalnej w Gorzowie. Diecezja nie chciała by majątek ten władze przekazały zakonom i w pismach do Wydziału wyznań PWRN w Zielonej Górze domagała się wydawania zakonom decyzji negatywnych w tej kwestii. Domagała się także od władz państwowych potwierdzania, że w wypadku likwidacji domu zakonnego dana nieruchomość w parafii przechodzi nieodpłatnie na własność parafii kościoła rzymskokatolickiego, bez żadnych warunków ${ }^{93}$. Dotyczyło to m.in. kanoników laterańskich, księży misjonarzy, oblatów. Diecezja chciała, aby władze wyznaniowe przekazywały własność zakonom na stan czasowej własności. Władze komunistyczne widząc

\footnotetext{
${ }^{88}$ AAN, sygn. 133/18, Informacja o stanie posiadania i działalności zakonów i zgromadzeń zakonnych na terenie województwa zielonogórskiego, k. 434.

${ }^{89}$ Tamże, k. 435.

${ }^{90}$ AAN, UdsW, sygn. 142/1, Informacja o aktualnej sytuacji i zasadach w pracy z zakonami, k. 240

${ }^{91}$ AAN, UdsW, sygn.133/60, Dane liczbowe dotyczące przeprowadzonych przez Wydziały wizytacji domów zakonnych męskich i żeńskich w latach:1967, 1968,1969, 19070 k. 19.

${ }^{92}$ Dz. U., 1971, Nr 16, poz. 150.

${ }^{93}$ ADZG, Zakony męskie różne 1966-1972, Pismo Wikariusza Generalnego do Prezydium WRN Wydział do Spraw Wyznań w Zielonej Górze z 18.05.1972 r., b.p.
} 
w tej sprawie dobry sposób na skłócenie zakonów z kurią biskupią, odmówiły spełnienia tego postulatu thumacząc się, że nie ma podstaw prawnych na takie czasowe rozwiązania, gdyż pojęcie własności czasowej jest sprzeczne z prawem cywilnym $^{94}$. Państwo przekazało zakonom nieruchomości będące $w$ ich dotychczasowym użytkowaniu. Przyznano im szereg kościołów, budynków mieszkalnych oraz grunty rolne ${ }^{95}$. Generalnie jednak, w parafiach obiekty sakralne były przekazane na własność diecezji, a nie zakonów ${ }^{96}$. W diecezji gorzowskiej wyremontowane za pieniądze zakonów kościoły i plebanie były przejmowane przez diecezję z przeznaczeniem dla księży diecezjalnych, np. kościół i plebania w Żarach odrestaurowane przez misjonarzy. Na własność zakonów przeszły trzy kościoły. Oblaci otrzymali kościół św. Józefa w Gorzowie, kapucyni kościół pw. św. Stanisława, lazaryści otrzymali kościół pw. MB Królowej Polski w Słubicach. Stan budynków oddanych zakonom był dobry i zakonnicy wykazywali dużą troskę o te obiekty. Oprócz budynków sakralnych, otrzymali również na własność budynki mieszkalne, np. kanonicy regularni budynek w Drezdenku, salezjanie w Dębnie. W woj. zielonogórskim przekazano 17 budynków mieszkalnych, 4 mieszkania, 10 ogrodów i sadów, 2 gospodarstwa rolne o areale 20 ha. Stan techniczny przekazanych budynków był różny ${ }^{97}$. Duże gospodarstwo rolne posiadali jedynie oblaci w Obrze - 17 ha. W opinii władz państwowych było ono dobrze zarządzane i uprawiane. Niektóre nieruchomości przejęte przez zakony były mocno zdewastowane i wymagały natychmiastowego remontu, na co też zakonnicy otrzymywali stosowne zezwolenia ${ }^{98}$. Władze wydawały też zgodę na budowę nowych plebanii. Jednak nie przeszkadzało to władzom, aby odmówić zgody oblatom na budowę nowego budynku seminaryjnego w Obrze. Wyraziły natomiast zgodę na budowę klasztoru kapucynom w Gorzowie ${ }^{99}$. W 1979 r. w woj. gorzowskim na 363 obiekty sakralne, 80 obiektów było pod władaniem zakonników, tj. $22 \%$. Na tym tle były konflikty między biskupem a zakonami ${ }^{100}$. Sprawa przejmowania nieruchomości wpłynęła na to, że w 2. połowie lat 70 . zakony na tym terenie nie nabyły formalnie żadnej nieruchomości. W tym okresie zakony nie zgłaszały też postulatów odnośnie do budowy nowych kościołów ${ }^{101}$. Władze nie notowały

${ }^{94}$ ADZG, Zakony męskie różne 1966-1972, Pismo Mieczysława Żywickiego kierownika Wydziału ds. Wyznań PWRN w Zielonej Górze do bp. Wilhelma Pluty z 15.06 .1972 r., b.p.

${ }^{95}$ AAN, UdsW, sygn. 142/1, Informacja o aktualnej sytuacji i zasadach w pracy z zakonami, k. 238.

${ }^{96}$ AAN, sygn. 133/18, Informacja o stanie posiadania i działalności zakonów i zgromadzeń zakonnych na terenie województwa zielonogórskiego, k. 435

${ }^{97}$ Dane te odnoszą się zarówno do zakonów męskich jak i żeńskich. AAN, sygn. 133/18, Informacja o stanie posiadania i działalności zakonów i zgromadzeń zakonnych na terenie województwa zielonogórskiego, k. 435.

${ }^{98}$ Tamże.

${ }^{99}$ AAN, sygn. 133/17, Informacja o stanie posiadania i działalności zgromadzeń zakonnych (męskich i żeńskich) na terenie województwa gorzowskiego wg stanu na dzień 30 czerwca 1980 r., k. 128.

${ }^{100}$ AAN, UdsW, sygn. 133/475, Sprawozdanie z działalności Wydziału IV za rok 1971, k. 1

${ }^{101}$ AAN, sygn. 133/17, Informacja o stanie posiadania i działalności zgromadzeń zakonnych /męskich i żeńskich/ na terenie województwa gorzowskiego wg stanu na dzień 30 czerwca 1980 r., k. 128. 
żadnych samowoli budowlanych, które by powiększyły stan posiadania obiektów zakonnych. Jedynie lazarysta ks. J. Kutermak, proboszcz w parafii Iłowa zakupił na własne nazwisko budynek we wsi Borowe, w którym urządził kaplicę i punkt katechetyczny ${ }^{102}$.

W realizacji polityki finansowej państwa wobec zakonów jednym z ważnych czynników było opodatkowanie. Pozwalało ono na wywieranie wpływu i nacisków na instytucje Kościoła. Polityka ta była uzależniona jedynie od doraźnych celów, jakie sobie w danym momencie stawiały władze. Podatki zakonnicy na tym terenie płacili regularnie i w terminie ${ }^{103}$. Nie odwoływali się też od wysokości naliczanego podatku.

Tak jak w poprzednim okresie, zakony były poddane nieustannej inwigilacji i rozpracowywaniu przez organa bezpieczeństwa. Bezpieka interesowała się wszystkim, co dotyczyło zakonów, stosując m.in. perlustrację korespondencji, bezpośrednią obserwację, technikę operacyjną (podsłuchy). Lokalna bezpieka, na polecenie kierownictwa resortu, ewidencją operacyjną objęła wszystkich zakonników. Sporządzała dokładne ich charakterystyki pod kątem wrogiego, lojalnego lub biernego nastawienia do nowego ustroju. Każdy zakonnik od momentu wstąpienia do nowicjatu miał w Ministerstwie Spraw Wewnętrznych założoną własną teczkę ewidencji operacyjnej (TEOK) ${ }^{104}$, do której bezpieka zbierała wszystkie informacje uzyskane na jego temat różnymi sposobami. Interesowała się planami oraz relacjami wewnątrz wspólnot zakonnych na podległym sobie terenie.

Wychodząc z zasady, żeby aby wroga zniszczyć, trzeba go dobrze poznać, priorytetowym celem działań władz państwowych „po linii zakonów” - tak jak przez cały okres komunistycznych rządów - było wciągnięcie do współpracy zakonników i osób z nimi związanych, aby przy ich pomocy sterować działalnością, skłócać wewnętrznie i dokonywać rozłamów we wspólnotach zakonnych. Władze starały się tworzyć, a następnie pogłębiać rozdźwięki między poszczególnymi zakonnikami, a biskupami, osłabiać aktywność zakonników w realizowaniu wytycznych Episkopatu oraz zachęcać do przeciwstawianie się im. Bezpieka starała się wykorzystać zakony przeciwko biskupom i wpływać na powstawanie w zakonach grup kontestujących działania Episkopatu ${ }^{105}$. Drogą działalności operacyjnej bezpieka dążyła do pogłębiania konfliktów między zakonami, a duchowieństwem diecezjalnym. Jednocześnie dążyła do tego, by spory między zakonami a duchowieństwem diecezjalnym lokalne władze rozstrzygały na korzyść tych ostatnich (np. w Gorzowie Wielkopolskim) ${ }^{106}$. Poprzez tajnych współpracowników, bezpieka zbierała informacje o planach działalności (jawnej i ukrytej) zakonów, wystąpieniach zakonników, relacjach wewnętrznych w zakonach, stosunku do biskupa,

${ }^{102}$ AAN, sygn. 133/18, Informacja o stanie posiadania i działalności zakonów i zgromadzeń zakonnych na terenie województwa zielonogórskiego, $\mathrm{k} 435$.

${ }^{103}$ Tamże, k. 436.

${ }^{104}$ E. Zając, Teczka na księdza (TEOK, TEOB, TEOP), „Arcana”, 4-5 (2006) s. 226.

${ }^{105}$ IPN, sygn. 0639/228, Notatka dot. problemów przedstawionych na spotkaniu Kierownictwa Departamentu w dniu 1 IV 1972 roku, k. 42.

${ }^{106}$ Informacja na temat planów pracy Wydziału V Departamentu IV MSW na lata 1978-1979, w: Plany pracy Departamentu IV MSW na lata 1972-1979, s. 304. 
kurii diecezjalnej. Podejmowała działania operacyjne wobec zakonników na tym terenie. Na przykład w 1973 r. lokalna SB założyła sprawę obiektową kryptonim Lisy na pracujących tutaj księży misjonarzy, kapucynów, werbistów i sercanów. Osobną sprawę pod kryptonimem Fanatycy założyła na pracujących w tym województwie salezjanów ${ }^{107}$. Domy i parafie zakonne były objęte rozpracowywaniem operacyjnym. W latach 70 . w związku z podjętą wtedy normalizacją stosunków państwo - Kościół, SB otrzymała polecenie prowadzenia przeciwko zakonom i całemu Kościołowi, działań nieoficjalnych, bardziej ukrytych, koncentrowania się na wyselekcjonowanych odcinkach pracy zakonów oraz stosowania ostrożnie i z rozwagą represji karnych ${ }^{108}$. Wydziały wojewódzkie Służby Bezpieczeństwa informowały na bieżąco MSW w Warszawie o poszczególnych zakonach (kierunkach i formach pracy, stopnia aktywności i zaangażowania, stanu powołań zakonnych) oraz możliwościach operacyjnych ,na odcinku zakonów”"109.

Praca nad zakonami w woj. gorzowskim przyniosła dla władzy pożądany skutek. Oceniając swoją pracę w drugiej połowie lat 70. w raporcie dla UdsW w Warszawie urzędnicy Wydziału do Spraw Wyznań z Gorzowa Wielkopolskiego pisali - „Zakonnicy stają na gruncie przestrzegania przepisów prawa. Są autentycznie zaangażowani w pracy duszpasterskiej. Wśród duchownych zakonnych brak manifestowanych publicznie postaw antypaństwowych. Książa zakonni ograniczają kontakty do własnego grona. Liczba parafii mimo wypowiadanych przez duchowieństwo [diecezjalne - D.Z.] opinii, nie maleje. Wskutek systematycznej pracy Wydziału zacieśniają się powiązania kleru zakonnego z organami władzy państwowej" "110. W planach pracy z zakonami na swoim terenie na kolejne lata, zamierzali nadal „pogłębiać izolację między klerem świeckim a zakonnym”, umacniać pozycję duchownych zakonnych kosztem duchowieństwa diecezjalnego oraz prowadzić systematyczne wizytacje domów zakonnych.

słowa kluczowe: Środkowe Nadodrze, zakony, Gorzów Wielkopolski, Służba Bezpieczeństwa, Polska Rzeczpospolita Ludowa, Urząd do Spraw Wyznań

${ }^{107}$ D. Śmierzchalski-Wachocz, Duchowieństwo rzymskokatolickie na Pomorzu Zachodnim, Środkowym i Ziemi Lubuskiej w świetle dokumentów państwowych z lat 1945-1989, t. I, Zielona Góra 2014, s. 292.

${ }^{108}$ IPN, sygn. 0639/100, zakres działania i zasady funkcjonowania pionu departamentu IV Ministerstwa Spraw Wewnętrznych z 1973 roku, k. 20-22; IPN, sygn. 0639/146, t. 2, Tezy na wykład do Rzeszowa, k. 136 a-p.

${ }^{109}$ IPN, sygn. 0639/52, t. 4, k. 41-46, 87-90, 91-92.

${ }^{110}$ AAN, UdsW, sygn. 133/17, Informacja o stanie posiadania i działalności zgromadzeń zakonnych (męskich i żeńskich) na terenie województwa gorzowskiego wg stanu na dzień 30.czerwca 1980 r, k. 131. 


\title{
THE COMMUNIST AUTHORITIES' POLICY WITH REGARD TO MALE RE- LIGIOUS ORDERS IN ŚRODKOWE NADODRZE IN THE YEARS 1970-1980
}

\begin{abstract}
Summary
In the 1970s in the Polish People's Republic, despite declaration of co-existence of the state and the Church, the Communists continued to fight with the Church on the ideological plane and strived to weaken it and reduce its pastoral activity, and it especially referred to religious orders in Polish society. Those principles were implemented by the organs of administration and security in Środkowe Nadodrze. During that period, they tried to lead a flexible policy with regard to religious orders. According to the top-down decisions, religious authorities tried to neutralize monks from the political influence of bishops. First, they sought, and with success, to make religious orders and congregations in that area loyal to them. They did that mainly through frequent individual conversations with monks and visits to religious houses. Then they continued to implement the task of forcing the orders to respect socio-political principles and binding state laws. They systematically analysed and then provided the Office of Religious Affairs in Warsaw with the information on the overall assessment of the current attitudes and activities of religious orders in their provinces. They monitored, on a regular basis, the relationships inside religious orders and their pastoral activities. They sought to set monks at variance with the local bishop and diocesan clergy. The actions taken by local governments towards religious orders brought the desired effect. Monks complied with the state regulations concerning the Church and they were not engaged in anti-socialist activities.
\end{abstract}

Keywords: Środkowe Nadodrze, religious orders, Gorzów Wielkopolski, the Security Service, the Polish People's Republic, the Office of Religious Affairs 